\title{
INITIATIVES IN THE AREA OF THE FINANCING OF THE EU BUDGET IN THE CONTEXT OF ENVIRONMENTAL PROTECTION ${ }^{1}$
}

\author{
ADRIÁN POPOVIČ
}

\begin{abstract}
In the article the Author discusses the structure of the EU budget initially, focuses on its revenue component and expenditure component and examines its status de lege lata. Subsequently, after this description, he describes the principles applied to the intended reform of the EU budget. Following the reform principles, the Author points out the recent initiatives of the environmental new own resource of the EU budget, whose primary objective is to comply with one of the most important EU policies, which is the environmental protection in accordance with the High-Level Group on Own Resources study from December 2016. In the end, the Author submits an evaluation of environmental own resources in the light of the presented reform principles of the financing of the EU budget.
\end{abstract}

\section{Keywords}

EU; own resource; environment; protection; initiatives

\section{JEL Classification: H61, H69, O44}

\section{Introduction}

The EU budget is one of the most problematic and one of the most complicated areas of European Law, Financial Law, and Tax Law. Of course, with regard to financing,

1 This article represents a partial output of the grant project VEGA no. 1/0846/17 "Implementation of the initiatives of the EU institutions in the field of direct taxes and indirect taxes and their budgetary law implications" and no. APVV-16-0160 "Tax evasion and tax avoidance (motivation factors, formation, and elimination)".

2 Internal Ph.D. Student, Department of Financial Law, Tax Law and economy, Faculty of Law, Pavol Jozef Šafárik University in Košice, Slovak Republic. The Author specializes in tax law and budgetary law. He is the author of more than 10 articles published in the Slovak Republic, Czech Republic and Poland. Contact email: adrian.popovic@student.upjs.sk. 
each Member State of the EU would want to contribute as little as possible to the EU budget and obtain as much as possible. However, the current system of the EU own resources has many shortcomings and, in addition to its complexity, this system suffers from the fact that many of its sources can be identified as the EU own resources only with difficulties and the funding of the EU should be achieved, under the Treaty on the Functioning of the European Union, by its own resources.

Many experts call for initiatives to reform the current way of financing the EU budget, simultaneously suggesting the different ways of its possible future financing. However, it is well known that the discussion about the reform of the EU budget is a "long distance run" and will not end with a simple consensus. It should be noted, that the opposite cannot be expected since this discussion leads to reducing the fiscal sovereignty of each Member State.

In accordance with the High Level Group on Own Resources study from December 2016, the effectiveness of the EU general budget depends on the ability (and the perception of this ability by the public) to solve the EU priorities and to help resolve the problems that European citizens face in their lives, whether economic, security, geopolitical, social or cultural problems.

This effort is not helped by the current funding system, which has gradually become a system of national contributions when the EU budget is perceived as a zero-sum game between "net contributors" and "net recipients". In addition, such a system could create an unsustainable ratio between payments and commitments, which needs to be monitored closely.

The reformed system of own resources could contribute to the achievement of EU policy goals and also to the task of adequately financing the EU budget and simplifying budget adoption. Many documents produced by the EU institutions state that EU citizens deserve a budget that addresses these problems directly when action is needed at EU level. Soon there will begin preparations for the next Multiannual Financial Framework. They will act in unique circumstances which could help overcome the traditional barriers to which the reform encountered on the revenue side. The future MFF will provide scope for a review of how the EU budget can support the Member States and European citizens more effectively, and it is very important to maximize this opportunity. This should be reflected on the revenue side and on the amount and composition of expenditure, in order to meet the EU budget targets and requirements for this budget (Monti et al.: 2016: 10).

In order to understand initiatives for reforming the EU's own resources in all contexts, it will be necessary to describe initially the structure of the EU budget, conditional upon the current legal status in which we bring to the reader the revenue part and the expenditure part of this budget. We would like to point out that while 
it will be a conceivable idea of a contribution of this article to bring the possible own resources of the EU budget as the revenue side of the budget in the context of environmental protection, we cannot forget on the description of the EU budget expenditures. These parts lead us to fulfill an overview of the budget and the "spirit" of the EU budget.

In the first part of the article, our scientific research will be ruled by several methods. However, it will be characterized in particular by the use of a systematic method and a descriptive method which will be used in analyzing the structure of the EU budget. These methods cannot be applied separately and we will be able to carry out scientific work that is not dogmatically aimed at a certain part of the problem.

One of the ideological goals of the paper is expressed in its second part, which discusses the planned reform of the EU budget. Specifically, in this section, we will focus on proposing possible new EU own resource to support EU environmental policy, which should be subjected to the principles of the budget reforming itself and which have long been under review not only by the EU institutions but also by the academic community and experts of European Law, Financial Law and Tax Law.

In addition to the abstraction method, which is inherent to the second part of this article, it will also be necessary to make extensive use of methods of analysis and synthesis. One of the logical methods characterizing this part of the work will be the method of induction as a process from special to general. We will use this in particular when assessing the nature of each possible new own resource of the EU budget. One of the most important methods we will use at the end of the paper will undoubtedly be a comparative method. ${ }^{3}$

The main ideological goal of the paper will be presented in the Conclusion, where we will evaluate the environmental own resources in the light of the presented reform principles of the financing of the EU budget.

\section{Revenues and Expenditures of EU Budget - de lege lata}

\subsection{Revenues of EU Budget}

The EU budget should be financed by own resources and other revenue ${ }^{4}$ in accordance with Art. 311 of the Treaty no. 2012/C 326/01 on the Functioning of the

3 In this sense, we will use both macro-comparison and international comparison, also bilateral and multilateral comparisons (Knapp, 2003: 88).

4 Other revenues are, for example, charges for the administrative operation of the institutions, fees relating to the functioning of the European Economic Area, fines, default interests, staff taxes of the EU institutions, an 
European Union (TFEU). As we mentioned above, own resources are assigned once and for all to the EU to finance its budget, which automatically becomes income of this budget without the need for any additional decision by the national authorities. The EU's total revenues must be in line with overall spending, moving within the agreed legal limits. Between 2014 and 2020, the EU can, under the new rules, acquire own funds for payments up to $1.23 \%$ of the sum of all Member States' GNIs. The total commitment appropriations shall not exceed $1.29 \%$ of EU GNI.

In order to highlight the latest proposals for reforming the financing of the EU budget, it seems justified to present the types of own resources of this budget for the period 2014-2020 (Leen, 2011: 205). The rules for the current seven-year budgetary cycle stipulate the following types of own resources:

- Traditional own resources (ie, in particular, customs duties and sugar levies) (Bujňáková, 2009: 69-73; Prievozníková, 2008: 148). Customs duties and agricultural levies result from the use of EU customs legislation and the common agricultural policy for imports from third countries. Sugar levies are imposed on sugar producers and used to cover EU spending in this sector. The advantage of traditional own resources is that they do not affect the Member States' budgetary balances and do not burden the Member States in which they are levied because they retain a part of the funds collected to cover the collection costs (König, Lacina, 2004; König et al.: 2009).

- Own resource based on the value-added tax (VAT). This form of funding was introduced due to the lack of EU budget revenue to date. Each Member State's harmonized VAT assessment bases are charged at a flat rate of $0.3 \%$ and the VAT taxable amount is limited to $50 \%$ of their Gross National Income (GNI) for the Member States. However, this is not a real tax-based own income, but only a method of calculating the Member State's contribution (Begg et al.: 2009: 7; Leen, 2013: 6-8). The harmonized VAT base shall be calculated in accordance with the provisions of Council Directive 2006/112 / EC on the common system of value added tax (Štrkolec, 2013: 398-409).

- Own resource based on gross national income (GNI). These resources are obtained by using a rate determined each year in the framework of the budgetary procedure on a basis representing the total quantity of GNI in market prices (Beličková et al.: 2010: 173). It is also possible to describe them in such a way that the standard percentage of GNI of each Member

income from lending and borrowing, and in particular a surplus from the previous budget. In general, however, if there were no budget surpluses, this group of revenue would be almost negligible. For instance Regulation (EEC, Euratom, ECSC) no. 260/68 of the Council laying down the conditions and procedure for applying the tax for the benefit of the European Communities, or Council Regulation (EU) 2016/300 determining the emoluments of EU high-level public office holders. 
Initiatives in the Area of the Financing of the EU Budget in the Context...

State is selected for expenditure not covered by other own resources in order

to achieve a balance between EU revenues and expenditures.

It cannot be omitted that selected Member States have claimed various corrections aimed at reducing their own share in the financing of the EU budget. Reliefs and other forms of corrections for the Member States have become one of the most contentious aspects of the current EU budget financing system. One way of looking at modifying the financing of the EU budget is that these corrections are generally the result of a failure in the budgetary process, including the EU budget spending component. This means that if there is a need to introduce a certain correction for the benefit of a Member State, it is generally better to make such a correction on the revenue side, not to distort the EU budget expenditures (Begg et al.: 2009: 13). This is one of the main reasons why those Member States and EU institutions have long been calling for a reform of the way in which EU revenue is collected.

\subsection{Expenditures of EU Budget}

Even though we do not intend to spend too much interest on the expenditures of the EU budget, we cannot omit this component in order to understand the structure of the EU budget.

Commitments as a part of the EU budget expenditures are divided into five headings through the seven-year financial framework ${ }^{5}$ for $2014-2020^{6}$, namely:

1) Smart and inclusive growth:

a) Competitiveness for growth and jobs.

b) Economic, social and territorial cohesion.

2) Sustainable growth: natural resources (including market-related expenditure and direct payments).

3) Security and citizenship.

4) Global Europe.

5) Administrative expenditure (for all EU institutions).

6) Special instruments.

Besides that, payment appropriations are budgeted for each year, the budget reserve is determined for exceptional cases, and at the end, a maximum own resources ceiling is set, up to $1.23 \%$ of the total GNI of all Member States. Each

5 The multiannual financial framework (MFF) defines the annual general budgets of the European Union. It defines how many funds total and how many different areas of action the EU could use each year if it adopts legally binding obligations for a period of at least 5 years. The most recent MFF normally covered 7 years.

6 Council Regulation (EU, EURATOM) no. 1311/2013 laying down the multiannual financial framework for the years 2014-2020. 
year, therefore, the estimated budget is determined, and data from the multiannual financial framework could be appropriately altered while preserving the envisaged process. $^{7}$

\section{Reform of EU Own Resources in the Context of Supporting EU Policy on Environmental Protection}

One of the most important features of state sovereignty is the right to impose taxes and fees on citizens. This does not only belong to every EU Member State but also to every sovereign state. However, this is contrary to the status of the EU as an integration group, as it is neither a federation nor a confederation, nor any other form of classical state organization. Therefore, it is necessary to approach this issue very carefully and it is necessary to not ignore the findings not only of the theory of law but also of the findings and research of the recognized Authors of the tax-legal science (Babčák, 2015).

The idea of changing the funding of the current EU own resources system is nothing new. Discussions on this issue have been ongoing for many years not only at national level but also at the transnational level (Monti, 2016: 2-3; De Feo, 2016: 63). The issue of reforming the EU's own resources is closely linked to the considerable need for reforming the EU budget, pointing in particular to corrections and derogations for those Member States in connection with the complexity of the current system (Laffan, 2016: 8). There is a need to establish an original financial instrument to ensure a fair and efficient financing of the EU budget in accordance with EU common policies (Kicová, 2011: 114-121).

The Amsterdam Treaty stipulated that "without prejudice to other revenue, the budget shall be financed wholly from own resources". The current system of funding, however, according to many experts, is contrary to this article. The third and fourth sources (VAT and GNI resource) of the EU budget are often considered as mandatory contributions by the Member States ${ }^{9}$, many of whom are not considered to be genuine EU own resources. In addition, the amount of these revenues and their structure are not decided by the autonomous EU institutions, but each one decision on own resources has to be approved by the national parliaments of the EU Member States. Finally, they ultimately have control over the fiscal policy of the EU

7 The Council, together with the European Parliament, adopts the annual EU budget under the special legislative procedure and on the basis of a Commission proposal, together with the European Parliament, may amend the annual budget and recommend to the European Parliament whether shall give a discharge to the Commission in respect of the implementation of the budget.

$8 \quad$ Article 311 (e.g. Art. 269 TEC) of the TFEU.

9 It is important to note that this third and fourth source of funding is required by the Member States under the threat of sanctions. 
Initiatives in the Area of the Financing of the EU Budget in the Context...

in relation to the financing of the EU budget. Although the current funding model is in fact functioning, a number of scientific authorities, as well as working groups directly Authorized by EU institutions, are exploring the possibilities of reforming the EU's own resources.

The reform of own resources should be guided by the different principles that should be followed in order to achieve the desired purpose in view of the nature of the new envisaged EU own resources. This is specifically about these principles (Monti, 2016: 9-16):

1) European added value - the EU budget needs to focus on areas bringing the highest "European added value", or on European public goods for which action at EU level is not only relevant, but indispensable, or where national financing possibilities are insufficient for achieving our European goals.

2) Subsidiarity - changes to the composition of EU own resources should respect the powers of the national authorities to decide on them; on the expenditure side, any reform should include a subsidiarity test to determine the level at which spending should be best undertaken: sub-national, national or European.

3) Budget neutrality - the size of the budget is firstly determined by the own resources ceiling and secondly by the MFF, i.e. on the expenditure side. The structure of EU financing does not, as such, have an impact on the volume of the EU budget.

4) Overall fiscal burden - new own resources do not aim to increase the fiscal burden for the EU taxpayer. On the contrary, a reduction in national contributions, combined with EU spending that is better geared towards policies with the higher added value such as security of external borders or defense, is also aimed at better European governance and can create savings for Member State budgets.

5) Improvement of the synergies - greater attention should be given to synergies between the EU budget and national funding for areas with a high European added value or where national financing possibilities are insufficient for achieving a European public good.

6) Unity of the budget - the unity of the EU budget should be explained and preserved, and "satellite" budgets should be limited to strictly justified cases and subject to proper parliamentary scrutiny.

7) Transparency of the EU budget - the EU budget and its financing should be more transparent and readable for citizens, so that the benefits of the EU, and not only its costs, are made visible. This would improve the overall accountability of the EU budget. 
8) Own resources should support EU policies - own resources should also be designed to support EU policies in key areas of EU competence: strengthening the Single Market, environmental protection and climate action, energy union, and reducing the fiscal heterogeneity in the Single Market.

At present, after many years of research and analysis in this area, and following these studies, there is a whole range of proposals of new own resources of the EU budget funding that could reform the current funding system. The reform itself should follow the above-mentioned principles. In accordance with the High-Level Group on Own Resources study from December 2016, there are proposed own resources of EU budget funding:

1. CO2 levy / Carbon pricing.

2. The inclusion of the EU Emission Trading Scheme proceeds.

3. Motor fuel levy (taxes on fossil fuels /excise duties).

4. Electricity tax-based own resource.

5. CCCTB, EU corporate income tax.

6. FTT - Financial Transaction Tax.

7. An alternative option to FTT: a bank levy or financial activities' tax (FAT).

8. A reformed own resource based on VAT.

9. Seigniorage.

Within the paper, we consider it important to point out, in particular, potential new own resources in the context of environmental protection (Sábo, 2013: 93-101). This is, mainly, the first four proposals for the new own resources of the EU budget, namely CO2 levy / Carbon pricing, inclusion of the EU Emission Trading Scheme proceeds, motor fuel levy (taxes on fossil fuels/excise duties) and electricity taxbased own resource. The key and direct impact of these possible new EU own resources could be the achievement not only increased environmental protection but also to maximize compliance with the aforementioned reform principles.

\subsection{CO2 Levy / Carbon Pricing}

Carbon pricing can take various forms, either in the form of taxation or in the form of market instruments. Carbon pricing can generally be seen as a tax on fossil fuels. $\mathrm{CO} 2$ levy should be imposed on all sources of greenhouse gas emissions and should have a significant impact on the costs and costs of the process in which they arise. Therefore, there is a presumption that it will stimulate the behavior of the consumer or the manufacturer in such a way as to favor another production process or other 
Initiatives in the Area of the Financing of the EU Budget in the Context...

type of consumption where fewer emissions could occur (Pearce, 1991: 938-940). Such behavior represents a significant advance in the fight against climate change, which is largely in line with EU policy (Luptáčik, Luptáčik, 2016: 2-3).

Although there are energy taxes in all Member States, and to a certain extent also harmonized at EU level, carbon taxes (or $\mathrm{CO} 2$ taxes) are less common. According to this harmonization, reference may be made to Council Directive 2003/96/EC restructuring the Community framework for the taxation of energy products and electricity, the main purpose of which is to avoid distortion of competition in the energy sector within the internal market (Eijndthoven, 2011: 284). This Directive establishes common rules for the Member States, namely what they should tax and when and what exemptions are permitted. Minimum tax rates, based in particular on the amount of energy consumed, are set for products used in the heating, electricity and motor fuels sectors. However, outside these minimum rates, Member States are free to set their own national rates (Štieberová, 2016: 73-79).

Several EU Member States have already introduced specific carbon and CO2 taxes ${ }^{10}$, but most environmentally-related taxes (in relation to greenhouse gas emissions) are imposed as part of the taxation of energy products and motor vehicles and they are not taxed directly on $\mathrm{CO} 2$ emissions.

In the latest proposal from the year 2011 to reform Directive 2003/96/EC, the European Commission planned to introduce a single minimum $\mathrm{CO} 2$ tax rate (exactly $€ 20$ per ton of CO2) for all sectors not covered by the EU ETS. ${ }^{11}$ After three years of negotiating and amending the text, the European Commission has assessed that the original text has changed so much that it no longer recognizes the main points of the original proposal. Therefore, this proposal was officially withdrawn on 7 March 2015.

An alternative could be the indirect carbon tax on consumption (product taxation, not taxation of a production), the amount of which would be determined by how much $\mathrm{CO} 2$ would be produced during the production of certain products, regardless of whether the whole or part of the production process takes place in within or outside the EU. Such a carbon tax was analyzed in detail in a study commissioned by the European Economic and Social Committee, which was positively evaluated as a prospective study. One of the main advantages of this tax is that includes the consumption of not only imported but also locally produced products. The $\mathrm{CO} 2$ content would be measured using $\mathrm{I} / \mathrm{O}$ models taking into account the entire

10 Currently, Denmark, Ireland, Finland, Sweden, France and Slovenia have a carbon tax in place. However, national rates are fixed at very different levels and do not reflect the carbon price under the EU Emissions Trading System (ETS) (Monti et al.: 2016: 41).

11 This would in particular affect households, transport, smaller businesses and agriculture that are not covered by the EU ETS. 
production chain. Research has even concluded that for the year 2011 and the tax rate of $€ 40$ per ton of $\mathrm{CO} 2$ emissions, it would be possible to generate revenue of $1 \%$ of the EU GDP. It cannot be forgotten that, from the point of view of the EU's industrial competitiveness, this approach is a challenge and it is questionable whether the most affected sectors of industry will not be involved in diminishing the adoption of such a kind of EU own resource (Monti et al.: 2016: 41).

\subsection{Inclusion of the EU Emission Trading Scheme Proceeds}

The European Emissions Trading Scheme (EU ETS) has been introduced in several successive steps as a key tool for combating climate change and as a means of reducing industrial greenhouse gas emissions (Medarova-Bergstrom et al.: 2012: 4-6). This system currently covers about $45 \%$ of the total amount of greenhouse gas emissions produced in the $28 \mathrm{EU}$ Member States. Emission quotas are allocated to a specific Member State and subsequently auctioned. The market stability reserve was only recently created as a result of the surplus of market certificates. This surplus occurred after the outbreak of the economic crisis, which itself reduced production and associated production of emissions more than expected (Coria, Jaraité, 2015: 2-3; Monti et al.: 2016: 43-44).

The main purpose of the entire ETS is to reduce emissions to a predefined level. This system was not set up to achieve a steady profit or a certain share of the trading intended to the EU budget as its own resource. This option was first examined in the 2010 budget review, but the European Commission's subsequent proposals in 2011 did not recommend to continue with these activities, in particular for the following two reasons:

1. The economic impact of the ETS varies significantly from one Member State to the other due to the fact that the national economic structures and energy mixes are different.

2. 50\% of auction revenues are already earmarked to be used for climaterelated actions.

\subsection{Motor Fuel Levy (Taxes on Fossil Fuels ${ }^{12} /$ Excise Duties $^{13}$ )}

Taxation of motor fuels is at present an important source of national income in each EU Member State and is at the same time the most relevant source of tax revenue in the transport sector. The level of taxation is decided by the national governments themselves, but still within the limits (such as reduced rates of taxation and tax 
Initiatives in the Area of the Financing of the EU Budget in the Context...

exemptions) laid down in Council Directive 2003/96/EC. The revenue obtained then leads either to the national budgets of the Member States or, in some cases, the revenues lead to the entities below the national level.

From the point of view of own resources, two scenarios could be envisaged:

1. A full transfer of the revenue collected by from the Member States from the motor fuel tax to the EU level.

2. A partial share or percentage of the motor fuel tax collected by the Member States.

In the first case, there would be a major systemic change and there would be a very visible shift from the current EU budget financing system, which would be visible both at EU level and national level. Such a reform would most likely enhance harmonization and ultimately neutralize competition between the Member States through the level of taxation (Morris, Munnings, 2014: 1-4). Centralizing such a tax at European level would also be in line with Arts. 192 and 194 of the TFEU, which provide a legal framework for fiscal measures in relation to future environmental and energy policy. These provisions, which have already been introduced by the Treaty of Lisbon, are not yet used. It is also important that such own resource could cover the financing of a substantial part of the EU budget, but would also be in accordance with the European public interest (environmental protection). It is also important to point out that funding through this own resource would be in line with the European Energy Union initiative, which aims to gradually decarbonize the transport sector.

In the second case, to the EU budget would be given a certain proportion of the tax deducted from the fixed amount or percentage of the collected motor fuel taxes as a new own resource. This scenario would probably be more acceptable to the EU Member States, although harmonization, neutralization of fiscal effects between the Member States or promoting a common and stable fiscal environment policy would not be achieved so well as in the first case (Keen et al.: 2013: 2-20).

\subsection{Electricity Tax-Based Own Resource}

Electricity taxation already exists in all EU Member States. In most cases, the level of taxation is decided by national governments and parliaments, and the taxes obtained are part of national public revenues. EU legislation sets minimum levels of taxation and mandatory exemptions (such as tax exemptions).

There are different types of taxes on electricity that can be implemented:

1. Taxes on electricity production (e.g. Environmental/pollution taxes). 
2. Taxes on the transport of electricity (e.g. tax or levy on the use of public space).

3. Taxes on the sales of electricity (e.g. consumption taxes, environmental taxes).

The first two types of taxation are collected from electricity companies. The third type of electricity tax is paid by the consumer of electricity (whether household or company).

In this regard, it should be noted that consumers spend on average $6.4 \%$ of total electricity consumption. According to the Energy Union initiative, the European Commission has put forward important proposals to revamp the European electricity market. The expected result would be an improvement of the security of the distribution network, more integrated and transparent markets, greater market supply for the electricity consumer and making profits more efficient. Such a fundamental transformation of the electricity market should bring tangible benefits to households and companies.

How, however, we can substantiate such a tax at European level? The justification for the introduction of such a tax could in principle be justified by the fact that the integration of the internal market would lead to economic savings, the benefits of the manufacturing sector and, last but not least, to the benefit of consumers. Moreover, the current efforts to create a common international interconnected electricity grid only contribute to argumentation in favor of such a tax.

It is important to mention that such own resource has the great potential to finance a large part of the EU budget. The EU could also link the potential of this own resource with European environmental policy and energy saving policy. However, it is necessary to draw attention to the fact that any proposal to introduce an own resource based on electricity tax should take account of the fact that electricity production is generally covered by the ETS.

In conclusion, we can summarize why this tax could appear as an appropriate own resource to finance the EU budget. A number of analyzes favor the taxation of electricity before taxes on production and transport, especially for the following reasons:

a) Such a method is simpler, less expensive and more transparent to consumers through an electricity bill. All consumers pay their electricity bill with the counted tax. This would simply allow the European electricity tax to be passed on to the electricity bill, thereby increasing transparency and awareness on the question how the EU budget is financed. 
Initiatives in the Area of the Financing of the EU Budget in the Context...

b) The control of the usage and payment is already being done by the electricity companies, making this tax less prone to tax evasion.

c) Analyzes show that there is a ratio between electricity consumption and income level. Rich regions tend to consume more electricity than poorer regions. Taxation of consumers could, therefore, be re-distributive. Proportionality is lost, however, when there is compared specific households. The change in electricity prices may have a greater impact on poor households than on richer households (Kosonen, 2012: 10-16). This deficiency could be eliminated by compensatory mechanisms at national or European level (e.g. subsidies), respectively the conditions for exemption from the tax could be laid down in the legislation (or conditions for the application of the reduced rate of tax) (Monti et al.: 2016: 47).

\section{Conclusions}

Proposed own sources of the EU budget funding can also be referred to as environmental own resources, which means that their implementation could be expected in the short term to achieve a sustainable improvement in the quality of the environment. This is fully in accordance with EU policy in this area.

Compared to the current EU budget financing, a sufficient return could also be expected. Therefore, the proposed environmental own resources of EU budget funding are considered important to be subject to evaluation in the context of the reform principles.

1) European added value - the nature of the possible adaptation of these environmental own resources implies that their implementation would be most appropriate at the transnational level in order to ensure uniform application of harmonized legislation in all EU Member States, either in the form of regulations or directives. Top-level coordination of Member States could provide not only a very effective financing of the EU budget but could also serve as a means of preventing the speculative behavior of EU Member States' national lawmaking in this area. For environmental own resources, European added value appears to be sufficiently high.

2) Subsidiarity - the application of this reform principle is closely linked to the principle of European added value, yet it has a different application. In each Member State, there are likely to be significant differences in the set of financial obligations that they would have against the EU budget. This applies in particular to geographic variations, population density, industrial level and the extent of environmental pollutants, whether at the level of the production 
process or in the case of final consumers. An essential requirement for the successful implementation of environmental own resources will, therefore, be the precise determination of the scope of rights and obligations at the transnational and national levels. The subsequent development of the level of pollution, which is actually the justification for the introduction of these own resources, will need to be closely monitored and adapted to any further reforms (Babčák, Madliak, 2016: 53-59; Červená, 2005: 140-163).

3) Budget neutrality - this reform principle should be fulfilled in relation to environmental own resources. Regarding the volume of funds raised from this budget, even the assumed level of the yield from environmental own resources would allow dispensing with the disputed, currently applied own resources (for example, the VAT-based own resource). Abovementioned would also eliminate the shortcomings that the own resource based on VAT and the GNI-based own resource give rise, in terms of conceptual meaning, to own resources as we understand them in EU budget law.

4) Overall fiscal burden - by the effective implementation and rigorous interpretation of the binding text of EU legal acts could be successfully harmonize the legislation on the financing of the EU budget by its own resources, which will ultimately lead to more effective cooperation between Member States and a reduction in the cost of individual Member States' budgets. Nor should the overall tax burden on taxpayers be increased, but only if the conditions for the effective implementation of such EU budget financing are met. It is important to remember that by the introduction of new own resources should be simultaneously abandoned current funding. This approach can also be expected to be met with the principle of overall fiscal burden.

5) Improvement of the synergies - European added value in the area of environmental own resources is demonstrably high and coordinates with the direction of EU policy on improving the quality of the environment. In terms of efficiency, the achievement of European public interests could be ensured by harmonizing legislation in the EU Member States through regulations or directives adopted at EU level.

6) Unity of the budget - respecting the application of this principle could be achieved by rigorously following the other principles of the reform and by precise wording and by defining the set of rights and obligations that Member States will have in relation to the EU budget and the set of rights and obligations that national authorities will have at their disposal in order to the efficient financing of the EU budget.

7) Transparency of the EU budget - the regulation of reformed own resources and the definition of the rights and obligations of national authorities in the 
Initiatives in the Area of the Financing of the EU Budget in the Context...

financing of the EU budget should meet the requirement of simplicity and clarity that EU citizens, even without legal and economic education, should understand the contribution and purpose of financing the EU budget through environmental own resources. This requirement will be a major challenge in the future for all interested parties.

8) Own resources should support EU policies - as the nature of the environmental own resources as such essentially fulfills this requirement, the application of this reform principle should not pose a more serious problem, but this does not apply to the current system of financing the EU budget through a VAT-based own resource and a GDP-based own resource.

\section{References}

Babčák, V.: Europeizácia slovenského daňového práva (skutočnost' a vízia) (Europeanization of Slovak Tax Law (Reality and Vision)), Ius et Administratio no. 1 (2015).

Babčák, V.: Úvahy o daňových oprávneniach Európskej únie (Reflections on the European Union's tax entitlements), in: Dobrobičová, G., Sagan, S.: Implementacja prawa unijnego do systemów prawa krajowego w Polsce i na Słowacji po dziesięciu latach członkostwa w Unii Europejskiej (Implementation of EU law into national law systems in Poland and Slovakia after ten years of membership in the European Union), Rzeszów: Wydawnictwo Uniwersytetu Rzeszowskiego, 2015.

Babčák, V., Madliak, J.: Sankcie a princíp “Znečistovatel” platî” vo vybraných štátoch EÚ (Sanctions and the "polluter pays" principle in selected EU countries), Karlovarská Právní Revue no. 2 (2016).

Begg, I. et al.: Financing of the European Union Budget. Study for European Commission, Directorate General for Budget. Final report, 2009.

Beličková, K. et al.: Rozpočtová teória, politika a prax (Budgetary Theory, Policy and Practice), Bratislava: Iura Edition, 2010.

Bonk, F.: Vlastné dane Európskej únie - nevyhnutnost' úniovej integrácie? (The European Union's own taxes - the necessity of EU integration?), Právní Rozprawy 2015: mezinárodní vědecká konference oblasti práva a právních věd (Legal Discourse 2015: International Scientific Conference on Law and Legal Sciences), Hradec Králové: Magnanimitas, 2015.

Bujňáková, M.: Colné právo ako podsystém finančného práva (Customs law as a subsystem of financial law), Praha: Nakladatelství Leges, 2009.

Cattoir, P.: Options for an EU financing reform, Brussels: Notre Europe, 2009.

Červená, K.: Etika podnikania a priaznivé životné prostredie (Business ethics and a favorable environment), Historické, politicko-právne a filozofické aspekty práva a právnej kultúry (Historical, political, legal and philosophical aspects of law and legal culture), Košice: UPJŠ v Košiciach, 2005. 
Chaloupka, F.: How Effective are Taxes in Reducing Tobacco Consumption?, Valuing the Cost of Smoking, in: Jeanrenaud, C., Soguel, N.C.: Assessment Methods, Risk Perception and Policy Options, New York: Springer, 1999.

Coria, J., Jaraité, J.: Carbon Pricing: Transaction Costs of Emissions Trading vs. Carbon Taxes, CERE Working Paper no. 609 (2015).

De Feo, A.: EU Own Resources: Momentum for a Reform?, EU Own Resources: Momentum for a Reform? Florence: European Union Institute, 2016.

Eijndthoven, J.: Energy Taxation at European Level: What does it do for the Environment and Sustainability?, EC Tax Review no. 6 (2011).

Knapp, V.: Vědecká propedeutika pri právniky (Scientific propedeutics for lawyers), Praha: Eurolex Bohemia, 2003.

König, P., Lacina, L.: Rozpočet a politiky Evropské unie (The budget and policies of the EU), Praha: C.H. Beck, 2004.

High Level Group on Own Resources, First Assessment Report, 2014.

Keen, M. et al.: Planes, ships and taxes: Charging for international aviation and maritime emissions, Economic Policy, 2013.

Kicová, A.: Tax policy of the European Union and its influence on national legislation, in: Pawłowska, A., Grabowska, S.: Zasada pomocniczości wymiar europejski, narodowy, regionalny i lokalny (Subsidiarity principle - the European, national, regional and local dimension), Rzeszów: Wydawnictwo Uniwersytetu Rzeszowskiego, 2011.

Kosonen, K.: Regressivity of environmental taxation: myth or reality?, Taxation Papers: Working Papers no. 32 (2012).

Krenek, A., Schratzenstaller, M.: Sustainability-oriented EU Taxes: The Example of a European Carbon-based Flight Ticket Tax, FairTax - Working Paper Series no. 1 (2016).

Laffan, B.: Own Resources: The Need for a Reform, in: EU Own Resources: Momentum for a Reform?, Florence: European Union Institute, 2016.

Leen, A.: The Return of the Value Added Tax: A New Own Resource to Finance the Budget of the European Union, ATINER's Conference Paper Series no. 496 (2013).

Leen, A.: What an EU Tax Means (From Collective to Individual Net Positions), EC Tax Review no. 4 (2011).

Luptáčik, M., Luptáčik, P.: Analysis and quantification of a new fiscally neutral European tax Executive summary, European Economic and Social Committee, 2016.

Medarova-Bergstrom, K. et al.: Criteria for maximising the European added value of EU budget: the case of climate change, Brussels: Institute for European Environmental Policy, 2012.

Monti, M.: Summary Statement of Mario Monti's Keynote Introduction, in: EU Own Resources: Momentum for a Reform?, Florence: European Union Institute, 2016. 
Initiatives in the Area of the Financing of the EU Budget in the Context...

Monti, M. et al.: Future Financing of the EU - Final report and recommendations of the High Level Group on Own Resources, 2016.

Morris, D., Munnings, C.: Progressing to a Fair Carbon Tax - Policy Design Options and Impacts to Households, Issue Brief, 2014.

Pearce, D.: The Role of Carbon Taxes in Adjusting to Global Warming, The Economic Journal no. 407 (1991).

Prievozníková, K. Colné právo (Customs law), Žilina: Knižné centrum, 2008.

Sábo, J.: Pojem environmentálnej dane v kontexte daňovej politiky Slovenskej republiky (The concept of environmental tax in the context of the tax policy of the Slovak Republic), in: Ura, E., Stelmasiak, J., Pieprzny, S. (eds.): Assessment of Legal Model of Environmental Protection in Poland and Slovakia, Košice: Equilibria, 2013.

Štieberová, I.: Aktuálne výzvy vedy o daňovom práve v oblasti daňovej morálky (Current Challenges of Tax Law Science in the Area of Tax Morality), Zborník príspevkov zo spoločného zasadnutia katedier finančného práva Právnických fakúlt univerzít Slovenskej a Českej republiky (Proceedings of the Joint Meeting of the Financial Law Departments of the Faculty of Law of the Universities of the Slovak Republic and the Czech Republic), Bratislava: UK v Bratislave, 2016.

Štrkolec, M.: Intrakomunitárne a "extrakomunitárne" obchody a daň z pridanej hodnoty (IntraCommunity and "extra-community" trades and value added tax), in: Právo, obchod, ekonomika (Law, business, economics), Košice: UPJŠ v Košiciach, 2013.

EU: Treaty on the Functioning of the European Union: no. 2012/C 326/01.

EU: Regulation (EEC, Euratom, ECSC) no. 260/68, laying down the conditions and procedure for applying the tax for the benefit of the European Communities.

EU: Council Regulation (EU) no. 2016/300, determining the emoluments of EU high-level public office holders.

EU: Council Regulation (EU, EURATOM), no. 1311/2013 laying down the multiannual financial framework for the years 2014-2020. 